\title{
COVID-19 pandemic in the Middle East countries: coronavirus-seeking behavior versus coronavirus-related publications
}

\author{
Shohreh SeyyedHosseini ${ }^{1} \cdot$ Reza BasirianJahromi $^{1}$ (D)
}

Received: 4 September 2020 / Accepted: 28 May 2021 / Published online: 10 July 2021

(c) Akadémiai Kiadó, Budapest, Hungary 2021

\begin{abstract}
The spread of COVID-19 has created a fundamental need for coordinated mechanisms responding to outbreaks in different sectors. One of the main sectors relates to information supply and demand in the middle of this pandemic in the digital environment. It could be called an infodemiology. It is known as a promising approach to solving the challenge in the present age. At this level, the purpose of this article is to investigate the COVID19 related search process by field research. Data were retrieved from Google Trends in Middle Eastern countries alongside scientific research output of Middle Eastern scientists towards COVID-19 in Web of Science, Scopus, and PubMed. Daily COVID-19 cases and deaths were retrieved from the World Health Organization. We searched for descriptive statistical analyses to detect coronavirus-seeking behavior versus coronavirus releases in the Middle East in 2020. Findings show that people in the Middle East use various keyword solutions to search for COVID-19 in Google. There is a significant correlation between coronavirus confirmed cases and scientific productivity (January 2020-December 2020). Also, there is a positive association between the number of deaths and the number of scientific publications (except Jordan). It was a positive and significant association between online coronavirus-seeking behavior on Google (RSVs) and the confirmed cases (except Syria and Yemen). Furthermore, it was a positive relationship between RSVs and scientific productivity in the Middle East (except Bahrain and Qatar). From an infodemiological viewpoint, there is a significant correlation between coronavirus information demand and its information provision.
\end{abstract}

Keywords Coronavirus $\cdot$ Scientific productivity $\cdot$ Google Trends $\cdot$ Infodemiology $\cdot$ Middle East

Reza BasirianJahromi

rezabsrn@gmail.com

1 Department of Medical Library and Information Science, Bushehr University of Medical Sciences, Bushehr, Iran 


\section{Introduction}

On January 30, 2020, the Director-General of the World Health Organization (WHO), Tedros Adhanom, declared a public health emergency of international concern. COVID-19 is a respiratory infectious disease caused by SARS-COV-2 (Homolak, Kodvanj, \& Virag, 2020). On March 11, 2020, the WHO announced a pandemic due to the worldwide outbreak of the pandemic (Belli, Mugnaini, Baltà, \& Abadal, 2020). Since late June 2020, the pandemic has claimed more than 503,000 lives worldwide (https://www.who.int/emergencies/diseases/ novel-coronavirus-2019/situation-reports/).

Iran was the first Middle Eastern country affected by the pandemic, followed by Turkey, Saudi Arabia, Qatar, and Egypt (Baloch et al., 2020). In this region, as in other parts of the world, the public interest in COVID-19 reflects the people's attention and their tendency to follow preventive measures (Hu et al., 2020a, 2020b). With the increasing availability and use of the Internet in the Middle East, the public's attention to this fast-paced pandemic is often reflected in a digital environment. Such a fast-moving pandemic requires agile research techniques using real-time data collection (Walker, Hopkins, \& Surda, 2020). As COVID-19 can be considered the first global pandemic of this magnitude in the digital age, digital health solutions, which have reached a certain level of maturity but have not been widely established and accepted, can play a significant role in our response to the crisis (Fagherazzi, Goetzinger, Rashid, Aguayo, \& Huiart, 2020). One of the digital health solutions in the twenty-first century is Google Trends (GT), which can act as an online search engine tracking system on the Internet (Heerfordt \& Heerfordt, 2020; Hu et al., 2020a, 2020b; Walker et al., 2020). GT has a tremendous potential to act as an Internet search behavior for public users (SeyyedHosseini, Asemi, Shabani, \& CheshmehSohrabi, 2018).

Undoubtedly, the COVID-19 pandemic has had a significant impact on people's lives including their Health Information Search Behavior (HISB). This concept is described as purposeful behavior performed by an individual to find health information (Ebrahim et al., 2020). Theoretically, the HISB relates to Health Information Distribution (HID). HID monitors the health information trends and gaps between information supply and demand by applying recent ICTs (Eysenbach, 2006). Eysenbach (2002) introduced these types of studies as infodemiology, which can be defined as the epidemiology of information to address public health and policy decisions (Hu et al., 2020a, 2020b). Nonetheless, researchers can survey affected factors on health information in the digital age using an infodemiological approach.

Online data show that millions of people in the Middle East are infected with the coronavirus. It leads to web search displays in the GT, a valuable source of information on public health trends (Heerfordt \& Heerfordt, 2020). The health policy-makers can illustrate a logical health information supply and demand process by analyzing Google searches for COVID-19, plus the scientific productivity of the pandemic (Zhang, Zhao, Sun, Huang, \& Glänzel, 2020).

With this in mind, we look at the COVID-19 search trends by query data retrieved from Google Trends in Middle Eastern countries. Also, we explore the scientific findings of Middle Eastern scientists on COVID-19 in the Web of Science, Scopus, and PubMed. 


\section{Methods and materials}

\section{Select area}

The study population included all countries in the Middle East region. These 16 countries include Bahrain, Cyprus, Egypt, Iran, Iraq, Israel, Jordan, Kuwait, Lebanon, Oman, Qatar, Saudi Arabia, Syria, Turkey, the United Arab Emirates, and Yemen. Due to the purpose of the study, verified cases were examined. Furthermore, COVID-19-related deaths, the relative search volume index (RSV) in Google Trends related to the pandemic, and the scientific extraction of Middle Eastern scientists related to COVID-19 were explored from January 1, 2020, to December 31, 2020.

\section{Google trends search strategy}

The authors used a systematic approach to select database search terms. It should be borne in mind that people search the pandemic with various languages and calligraphy on Google. So, Google's Middle East keywords with different names and spelling were entered in Google Trends. The official languages, plus the commonly spoken languages of the region, were retrieved in English, Arabic, Persian, Turkish, Hebrew, Greek, Kurdish, French, and Russian. Key concepts were presented to the research team, and the initial search list terms were entered using the designation COVID-19. As shown in Table 1, extracted keywords including crown, coronavirus, Covid19, Covid-19, Covid 19, 2019nCOV and SARS-COV-2 (in English), Firus Korona, Korona, Kofid 19, Kofid-19, Kofid 19, دوك 19 دىفوك ، 19 (in Arabic), Corona, Coro-

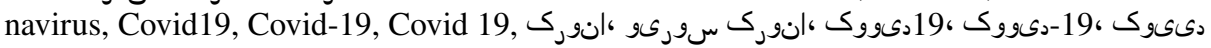
19 (in Persian), korona, korona virüs, kovid19, kovid-19, kovid 19 (in Turkish), הנורול

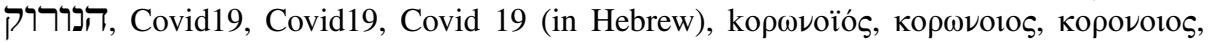
Covid19, Covid-19, Covid 19 (in Greek), vîrusa koronayê (in Kurdish), коронавирус, Корона вирус (in Russian), Coronavirus, Corona virus, Covid 19, Covid19, Covid-19 (in French). Keywords were selected with the consultation of some expert linguistics plus the natives, as the most common terms related to COVID-19 Middle Eastern countries. Then, Google Trends was used to explore the relative search volume (RSV) that "the share of requests for a particular term for a given location and period is normalized, with the highest share of queries from that term over time series and presented on a scale of 0 to 100" (Walker et al., 2020). In other word, search results are normalized to the time and location of a query by the following process ${ }^{1}$ :

- Each data point is divided by the total searches of the geography and time range it represents to compare relative popularity. Otherwise, places with the most search volume would always be ranked highest.

- The resulting numbers are then scaled on a range of 0 to 100 based on a topic's proportion to all searches on all topics.

- Different regions that show the same search interest for a term don't always have the same total search volumes.

${ }^{1}$. https://support.google.com/trends/answer/4365533?hl=en\&ref_topic=6248052 
Table 1 Search Queries in Google Trends on COVID-19 in Middle Eastern Countries

\begin{tabular}{|c|c|}
\hline Countries & $\begin{array}{l}\text { Keywords (based on Official Language as well as Commonly Spoken Language in } \\
\text { Middle Eastern Countries) }\end{array}$ \\
\hline Bahrain & 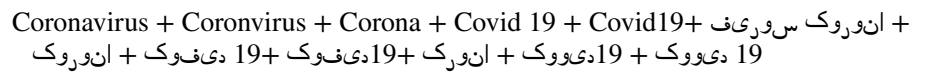 \\
\hline Cyprus & $\begin{array}{l}\text { Corona virus }+ \text { Coronvirus }+ \text { Corona }+ \text { Covid } 19+\text { Covid } 19+\text { kovid } 19+\text { kovid } 19+\mathrm{k} \\
\text { orona }+ \text { ko } \omega \text { voïó } \varsigma+\text { korona virus }+ \text { koronavirüs }\end{array}$ \\
\hline Egypt & 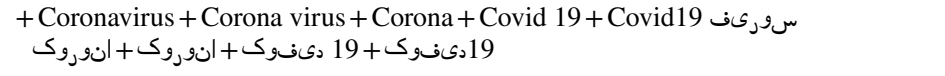 \\
\hline Iran & 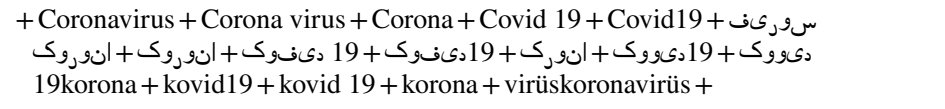 \\
\hline Iraq & 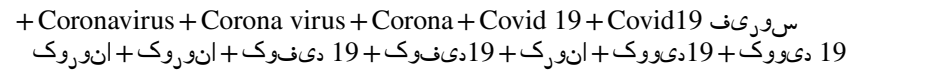 \\
\hline Israel & 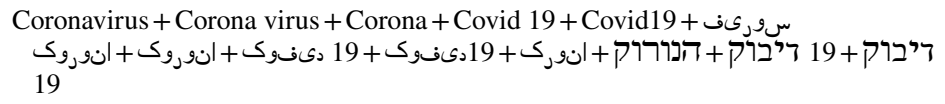 \\
\hline
\end{tabular}

Jordan

سورىف + Coronavirus + Corona virus + Corona + Covid 19+Covid19

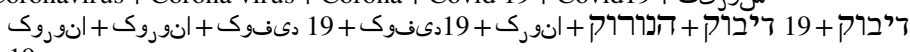
19

Kuwait

سورىف + Coronavirus + Corona virus + Corona + Covid 19+Covid19

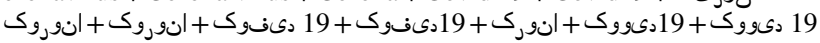

Lebanon

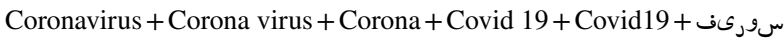

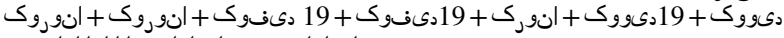

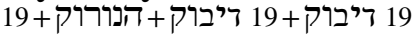

Oman

سورىف + Coronavirus + Corona virus + Corona + Covid 19+Covid19 انورك+19دىفوك +19 دىفوك+ انوروك + انوروى +Covar

Qatar

سورىف + Coronavirus + Corona virus + Corona + Covid 19+Covid19

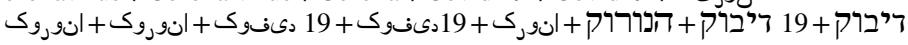
19

Saudi Arabia

سورىف + Coronavirus + Corona virus + Corona + Covid 19+Covid19+

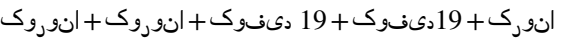

Syria

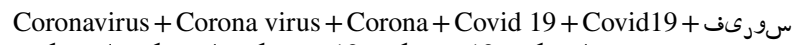
انورى+19دىفوى+19 دىفوى + انوروى+ انوروى +Covid

Turkey

سورىف + Coronavirus + Corona virus + Corona + Covid 19+Covid19

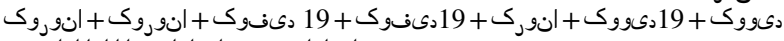
19 דיברק+19 19

سورىف + United Arab Emirates Coronavirus + Corona virus + Corona + Covid 19+Covid19

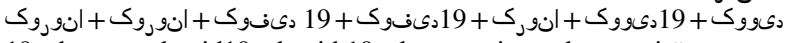
19 + korona + kovid19+ kovid 19+korona virus + koronavirüs

Yemen

Coronavirus + Corona virus + Corona + Covid 19+Covid19+

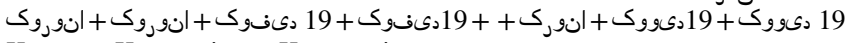

Korona + Koronavirus + Korona virus

We used the "+" feature to include several terms in one search in all languages containing special characters and accents. If necessary, we applied quotation marks, plus synonyms, regional variations, and language diversity in a given country to extract related keywords. For instance, in Cyprus, queries in Greek, Turkish, and English may be relevant; in Lebanon, French, Arabic, and English could be relevant; in Iran, Persian, Kurdish, English, Arabic, and Turkish will be related. 
Table 2 Search strategies for publications on COVID-19

\begin{tabular}{|c|c|}
\hline Database & Search strategy \\
\hline WoS & $\begin{array}{l}\text { TS = (“2019-nCov” OR “2019 novel coronaviru*” OR “2019 novel-coV” OR "COVID-19” OR } \\
\text { "SARS-CoV-2”) }\end{array}$ \\
\hline PubMed & $\begin{array}{l}\text { Search ((((“2019-nCov”) OR “novel coronaviru”) OR “2019 novel-coV”) OR “COVID-19”) OR } \\
\text { "SARS-CoV-2” }\end{array}$ \\
\hline Scopus & $\begin{array}{l}\text { TITLE-ABS-KEY ("2019-nCov" OR "2019 novel coronaviru*" OR "2019 novel-coV" OR } \\
\text { "COVID-19" OR "SARS-CoV-2") }\end{array}$ \\
\hline
\end{tabular}

Data were retrieved in daily-level on the time unit in Google Trends. Also, our search had no category restriction, and the field "All categories" was selected.

\section{Selected databases}

Confirmed cases of COVID-19 mortality in Middle Eastern countries, during the study period, were taken from the World Health Organization (WHO) website. These data were normalized on a scale of 0 to 100 to provide comparisons with search terms. The database search was reviewed, and, as mentioned earlier, part of the data was collected from Google Trends. This data can be used as a measure of public interest over time. Google Trends data was retrieved for web search queries for the term COVID-19, and its synonym in other official languages in the Middle East, for mapping information search behavior from January 1, 2020, to December 31, 2020.

\section{Article databases}

We selected Web of Science, Scopus, and PubMed as the three most prominent and well-known databases (Belli et al., 2020; Falagas, Ntziora, Makris, Malietzis, \& Rafailidis, 2009) for medical publications, especially Covid-19. Using a scientometric approach, we formulated a search strategy in the given databases during the study period as shown in Table 2.

The authors read the articles' abstracts carefully to ensure that all the retrieved documents being relevant. One of the most important inclusion criteria was that these documents have at least one Middle Eastern scholar as co-author. If any articles were authored by scholars from more than one Middle Eastern country, that document was counted for each country separately. The inclusion criteria of the manuscripts in the study were the online publishing date. All types of retrieved documents (original paper, review, etc.) were included in the study. Since some of the recovered records may overlap, we imported them into Endnote software, then enabled the "Duplicate discard" icon. Finally, after removing duplicates, 16,655 articles were retrieved from these three databases.

\section{Data analysis}

In the last step, we examined the data graphically and then formally tested it with the Kolmogorov-Smirnov test. As data were not normally distributed, the Spearman rank 
correlation was used to test the strength of the association between RSV and scientific productivity. We used daily data for all variables. In scientific publications data, we counted the publications monthly and then calculated the mean of the publications per day. Then we designed the map of the number of search terms related to the coronavirus. The data analysis process was performed using SPSS software.

\section{Findings}

\section{Number of confirmed cases and deaths related to COVID-19 in the Middle East countries}

As shown in Table 3, the first confirmed cases of COVID-19 during the study period were identified in the Middle East in January 2020 in the UAE. However, since February 2020, as the pandemic grew increasingly, the number of confirmed cases increased significantly, too.

According to Table 3, the first established case of COVID-19 in the UAE was reported in January 2020 with eight patients. Other rankings were Iran (February 18), Israel and Lebanon (February 21), Iraq, Kuwait and Oman (February 24), Bahrain (February 25), and Qatar (February 29) in May 2020, respectively. Approved cases had been experienced a varied fluctuation during the period of the study. Turkey, Iran, and Iraq had the highest number of confirmed cases in 2020, accordingly.

The first Covid-19 death was reported on 18 February 2020 from Iran. According to Table 4, the number of deaths had been experienced various fluctuation during the study. Previously, this was happening to the confirmed cases. Iran, Turkey, and Iraq had the highest number of deaths, respectively.

\section{The information-seeking behavior of the middle east people on Google relating to the COVID-19 from Jan 1, 2020, to Dec 31, 2020}

We have drawn the key cases of the corona virus that Google searched for in the Middle East. As shown in Fig. 1, GT was used to extract the data.

As shown in Fig. 1, RSVs of the COVID-19 outbreak in the middle east countries has been experienced the highest frequency in April $2020(n=7)$. The highest RSVs for each country during the period of the study is listed below: Bahrain (9 Apr), Cyprus (3 Aug), Egypt (1 Apr), Iran (22 Feb), Iraq (1 Apr), Israel (14 Mar), Jordan (6 Apr), Kuwait (7 Apr), Lebanon (26 Jul), Oman (6 Apr), Qatar (13 Jul), Saudi Arabia (1 Jul), Syria (14 Mar), Turkey (25 Nov), United Arab Emirates (6 Jul), Yemen (10 Apr). The graphs indicated that there was a fluctuating flow in coronavirus-related searches between January to December 2020 .

\section{The distribution of the scientific productivity of the middle east scholars on scientific databases relating to the COVID-19 from Jan 1, 2020, to Dec 31, 2020}

Of 16,655 coronavirus-related articles published by middle east scholars, Iranian scholars had the highest number of publications relating to the COVID-19 $(n=3,854)$ from Jan 1 , 


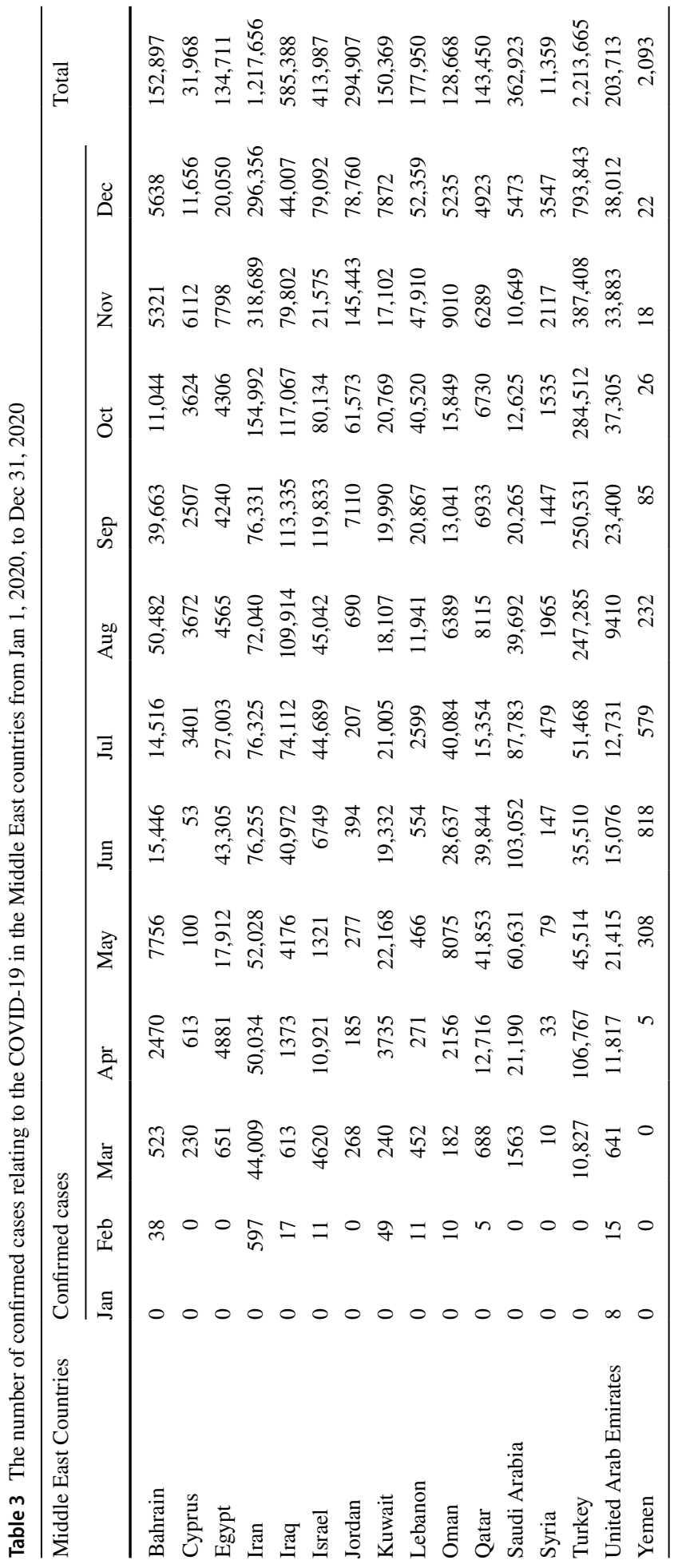




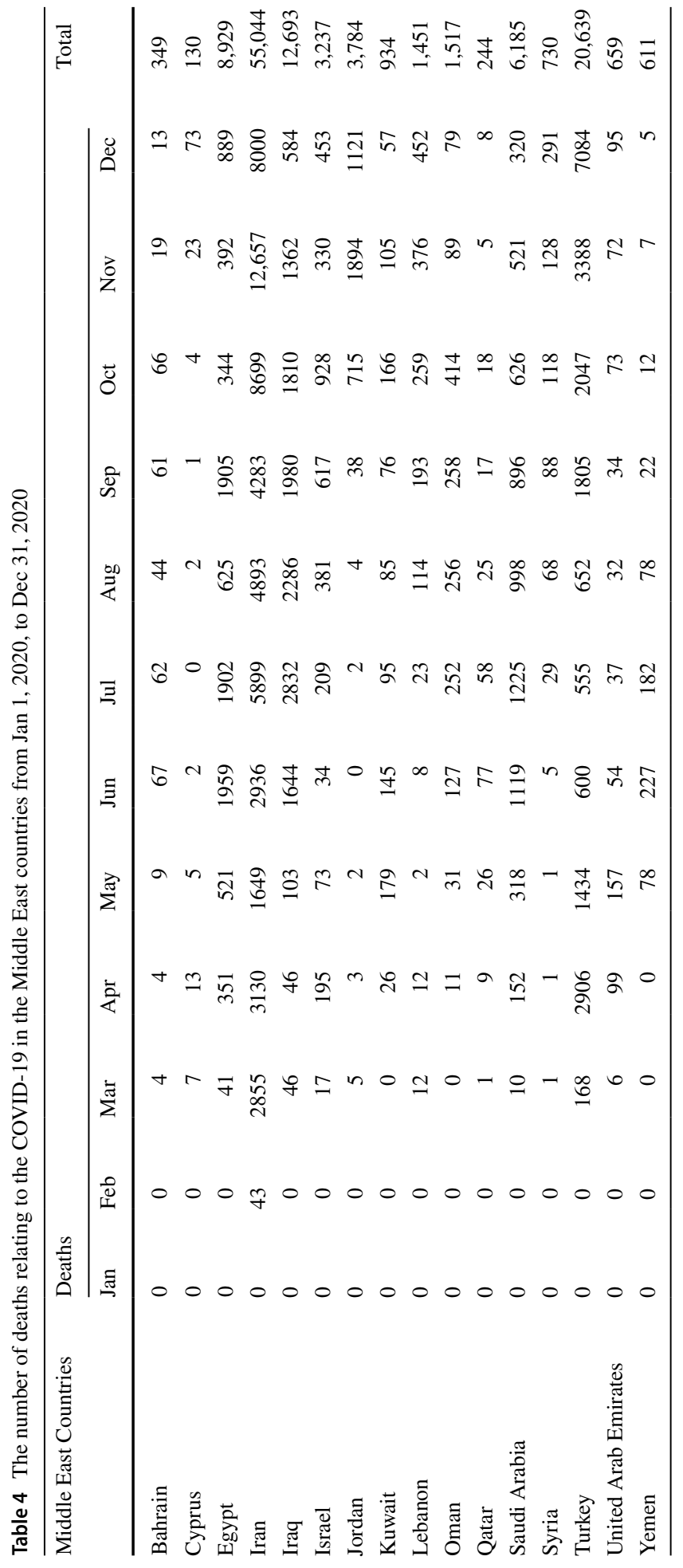


Bahrain

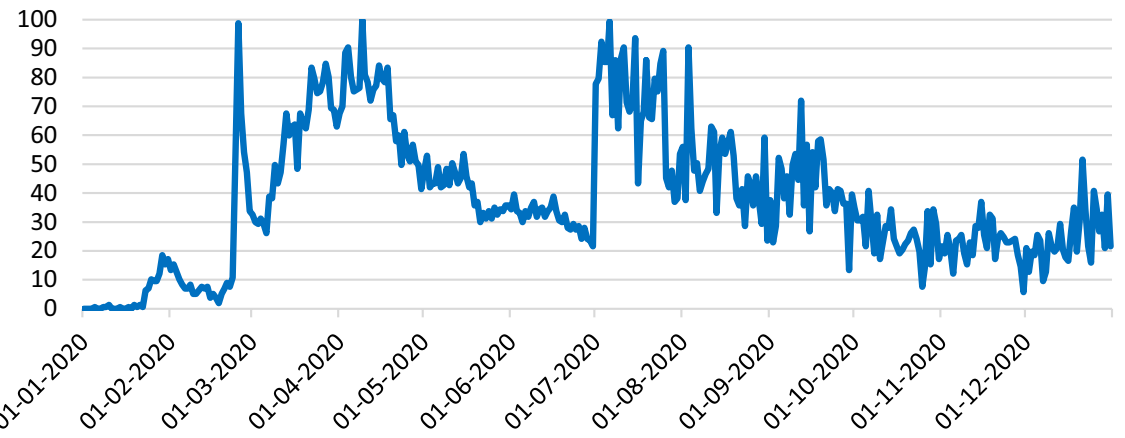

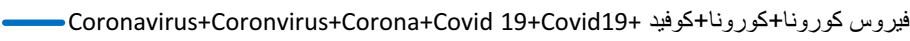
19+كوفيد19+كرونا+كوويد19+كوويد 19

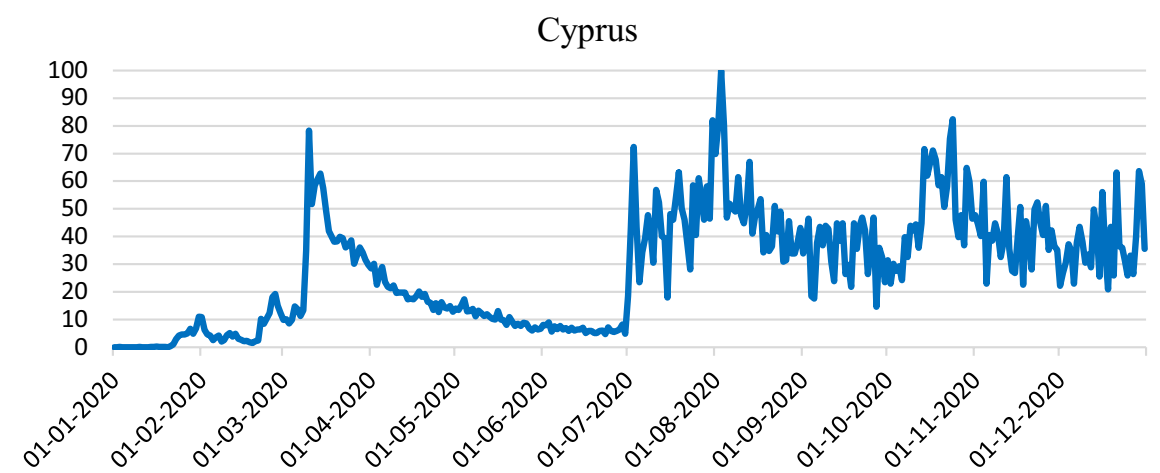

Corona virus+Coronvirus+Corona+Covid 19+Covid19+kovid 19+kovid19+korona+kopwvoïó + +korona virüs+koronavirüs

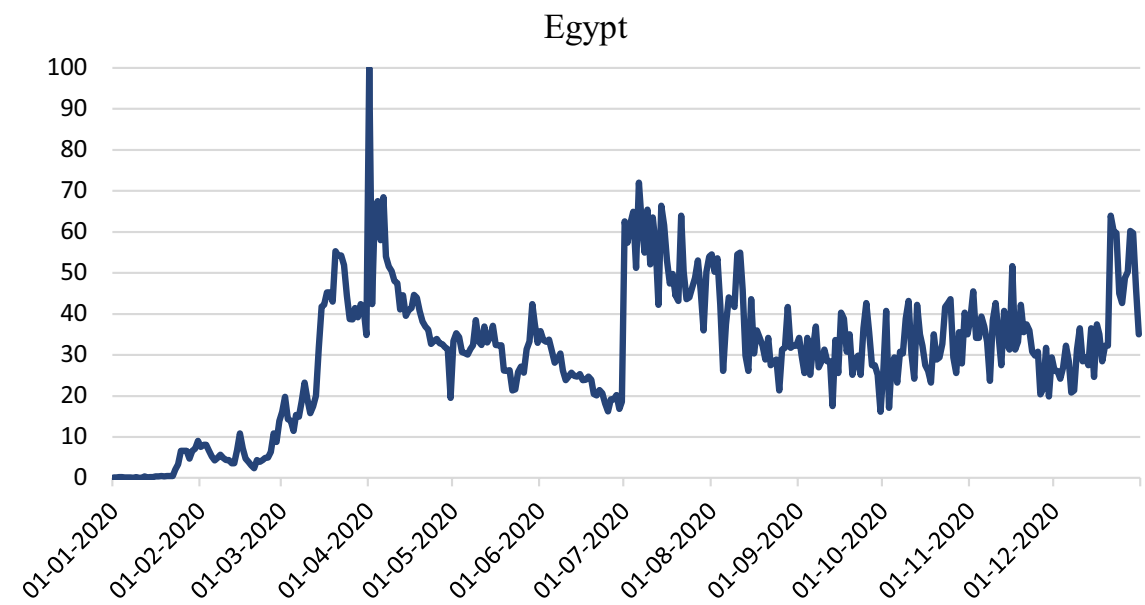

Coronavirus+Corona virus+Corona+Covid 19+Covid19+19 فيروس كورونا+كورونا+كوفيد 19+كوفيد

Fig. 1 The relative search volumes (RSVs) on Google relating to the COVID-19 
Iran

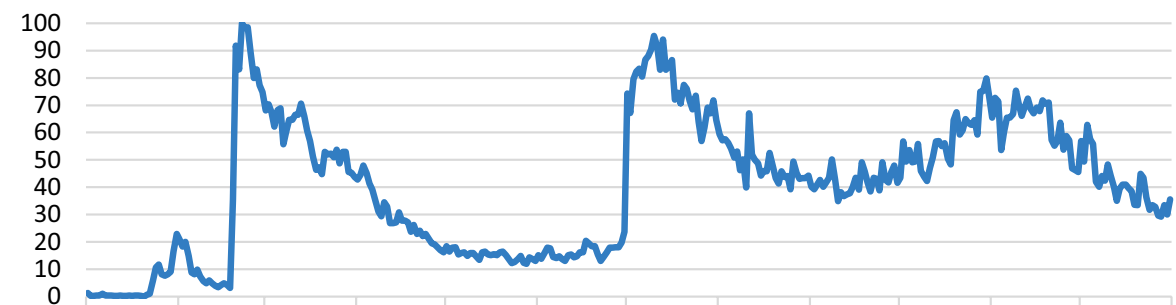

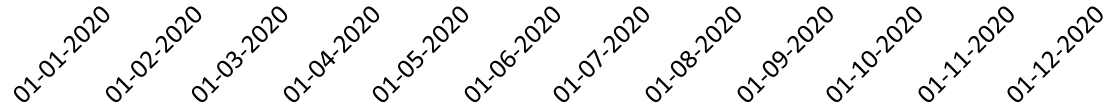

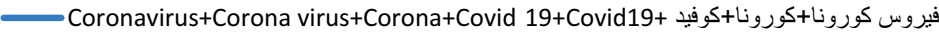

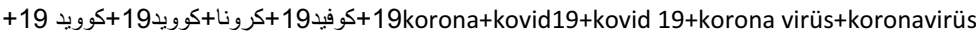

Iraq

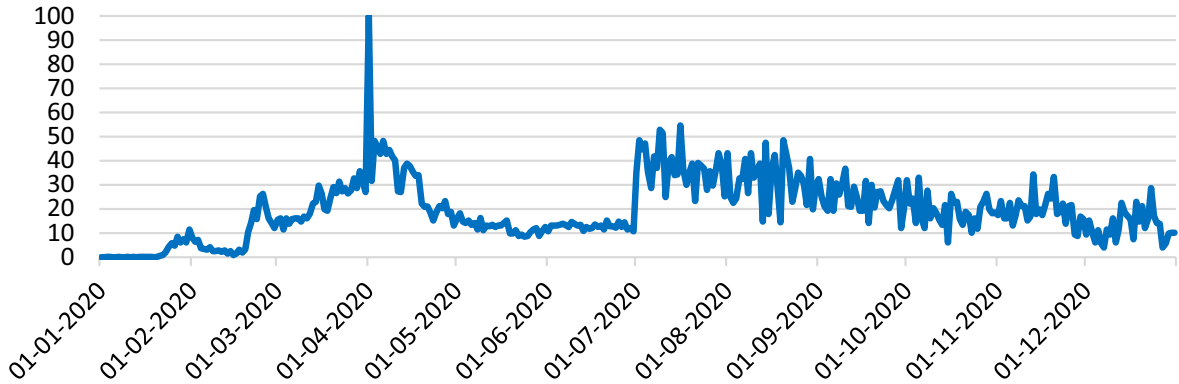

فيروس كورونا+كورونا+كوفيد +Coronavirus+Corona virus+Corona+Covid 19+Covid19 19+كوفيد19+كرونا+كوويد19+كوويد 19

Israeal

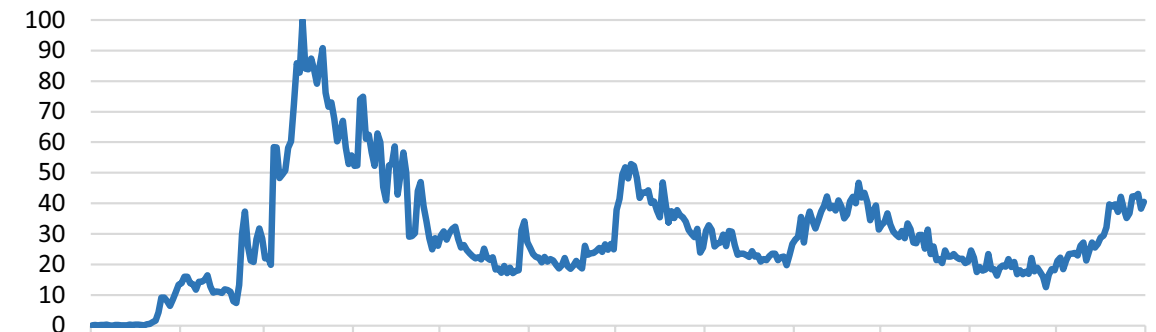

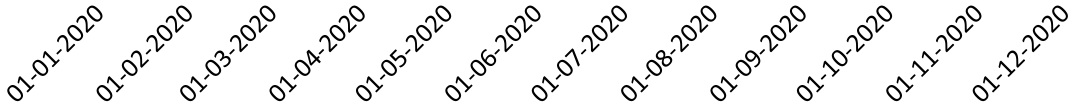

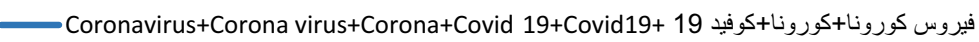
+كوفيد19+كرونا+קורונה+קוביד 19+קוביד 19

Fig. 1 (continued) 


\section{Jordan}

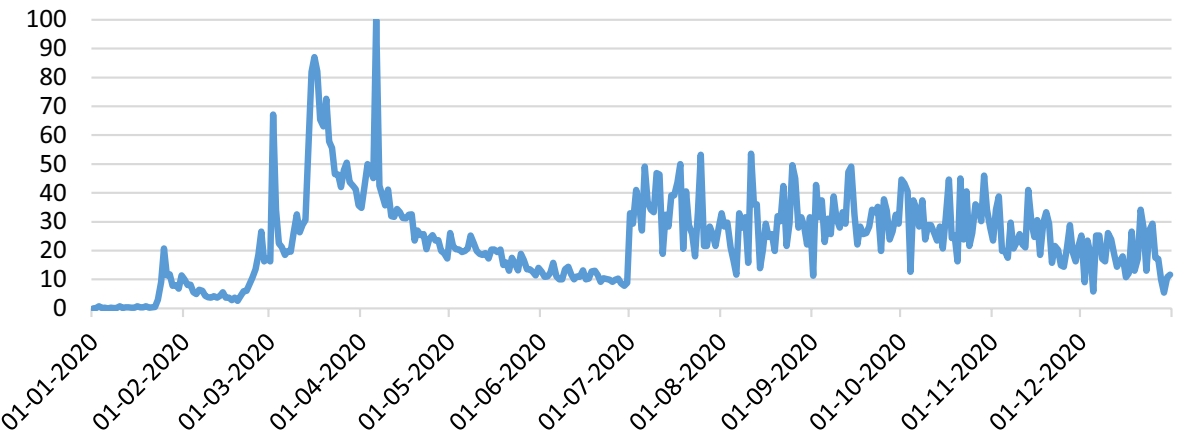

فيروس كورونا+كورونا+كوفيد 19 +Coronavirus+Corona virus+Corona+Covid 19+Covid19+ +كوفيد19+كرونا+קורונה+קוביד 19+קוביד 19

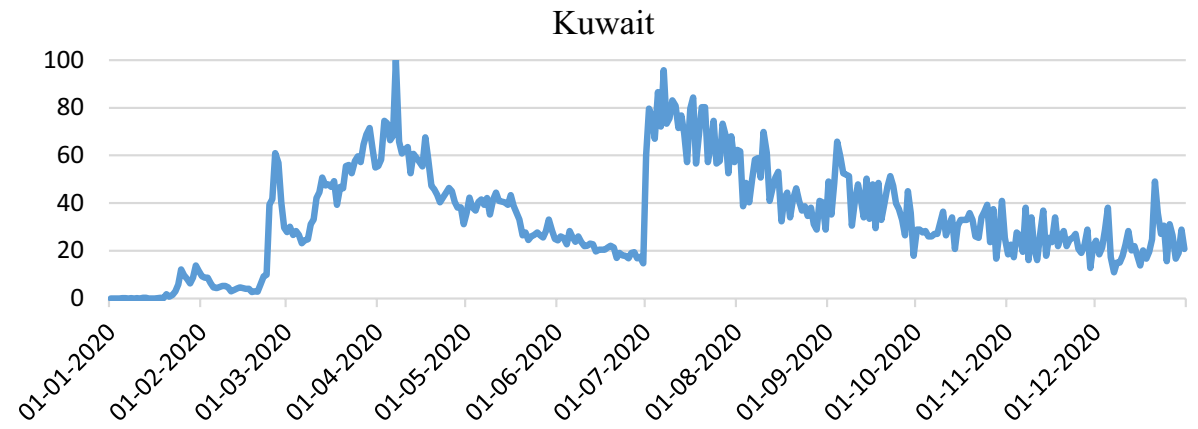

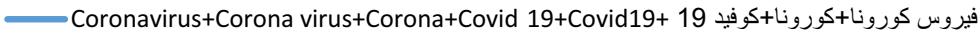
+كوفيد19+كرونا+كوويد19+كوويد 19

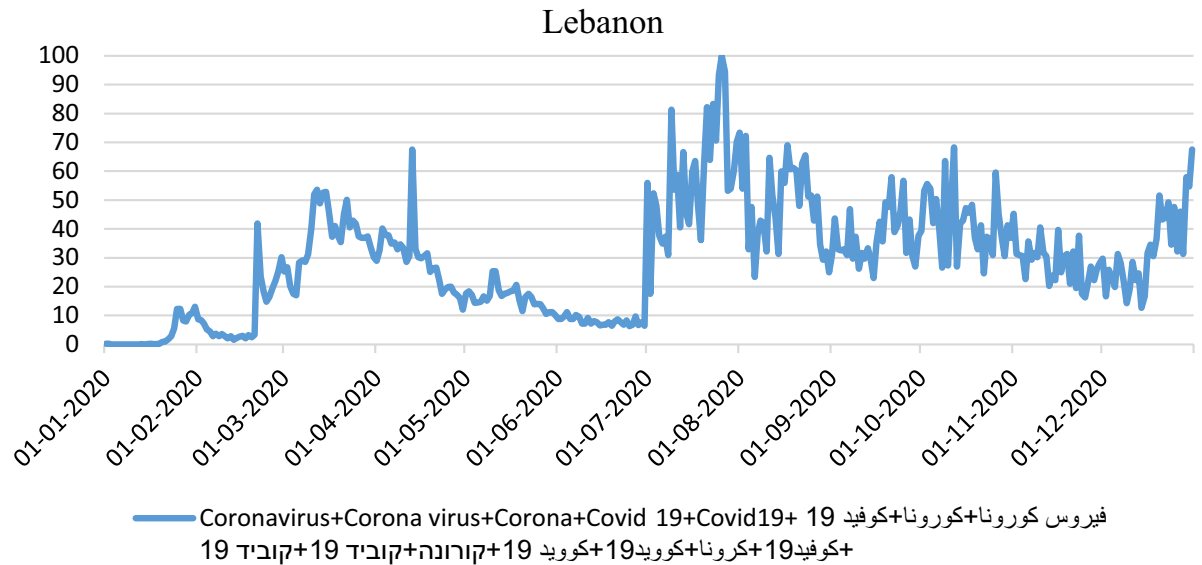

Fig. 1 (continued) 


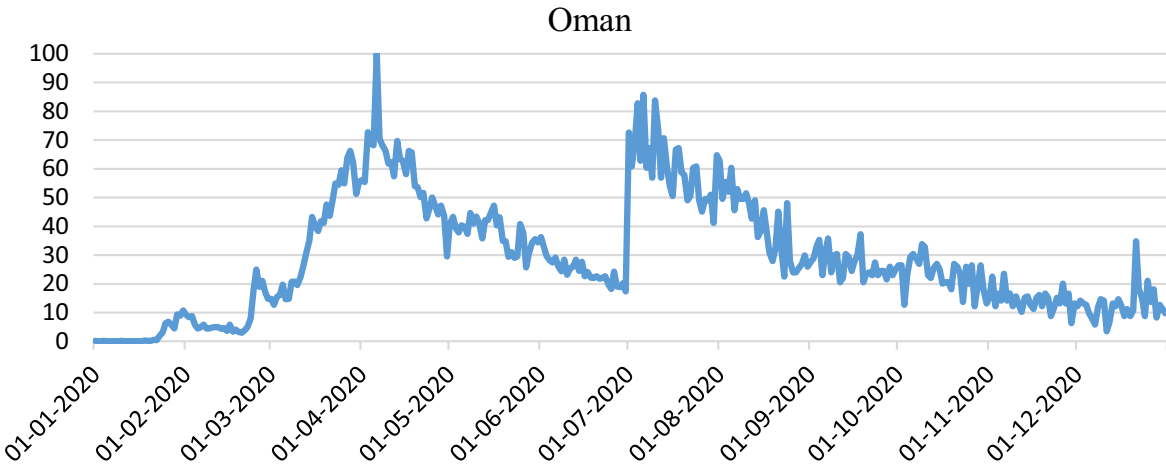

فيروس كورونا+كورونا+كوفيد 19+كوفيد19+كرونا+Coronavirus+Corona virus+Corona+Covid 19+Covid19

Qatar
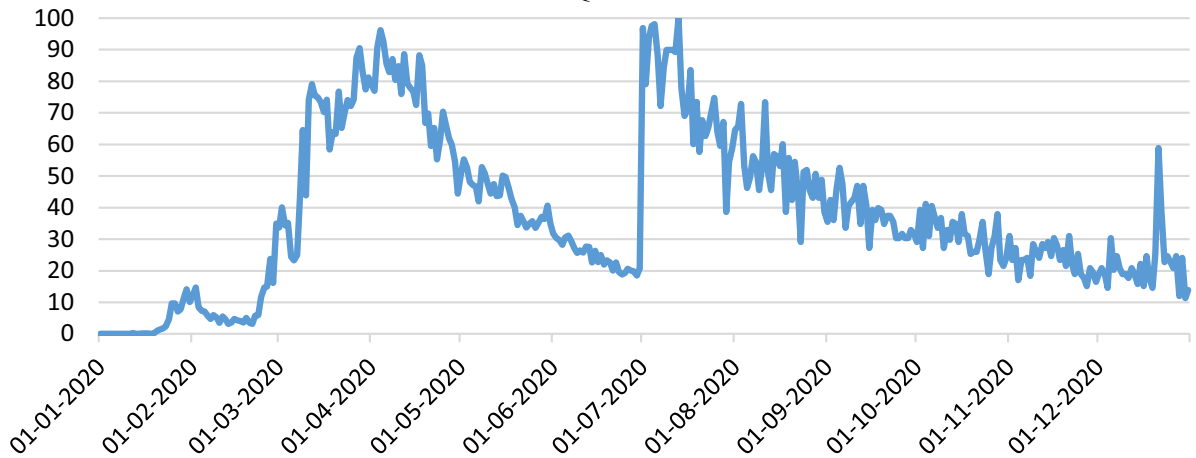

فيروس كورونا+كورونا+كوفيد 19+كوفيد19+كرونا+Coronavirus+Corona virus+Corona+Covid 19+Covid19

Saudi Arabia

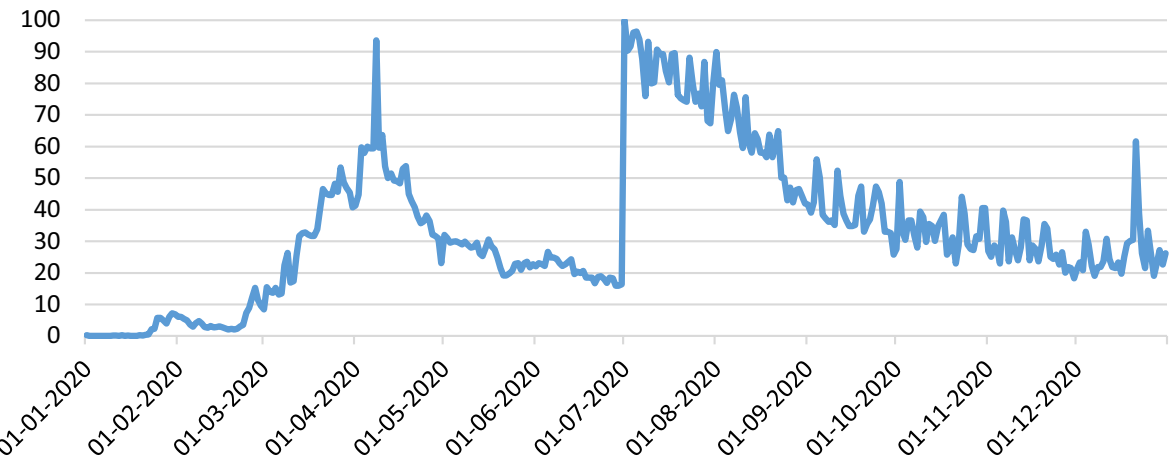

فيروس كورونا+كورونا+كوفيد+19 كوفيد19+كرونا+Coronavirus +Corona virus+Corona+Covid 19+Covid19

Fig. 1 (continued) 


\section{Syria}

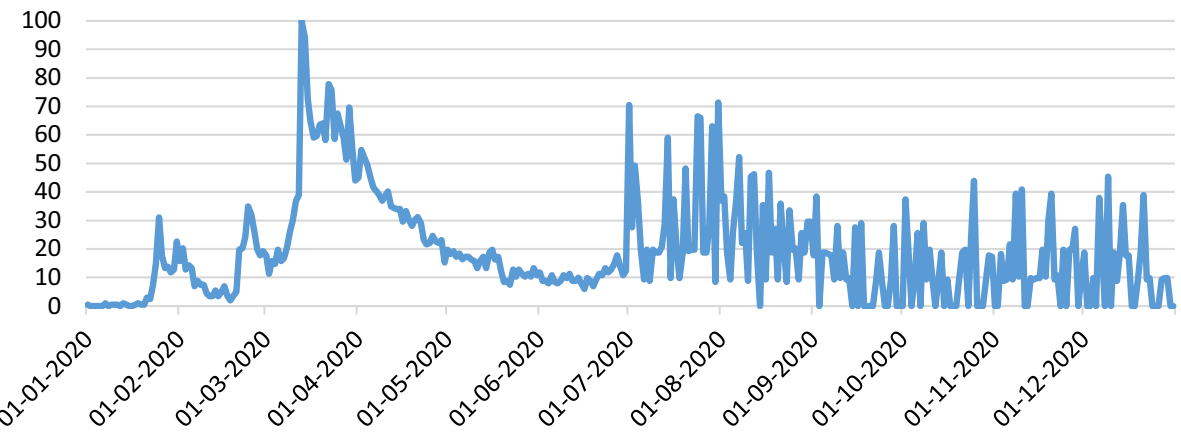

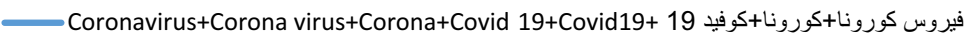

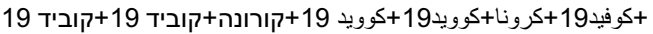

\section{Turkey}
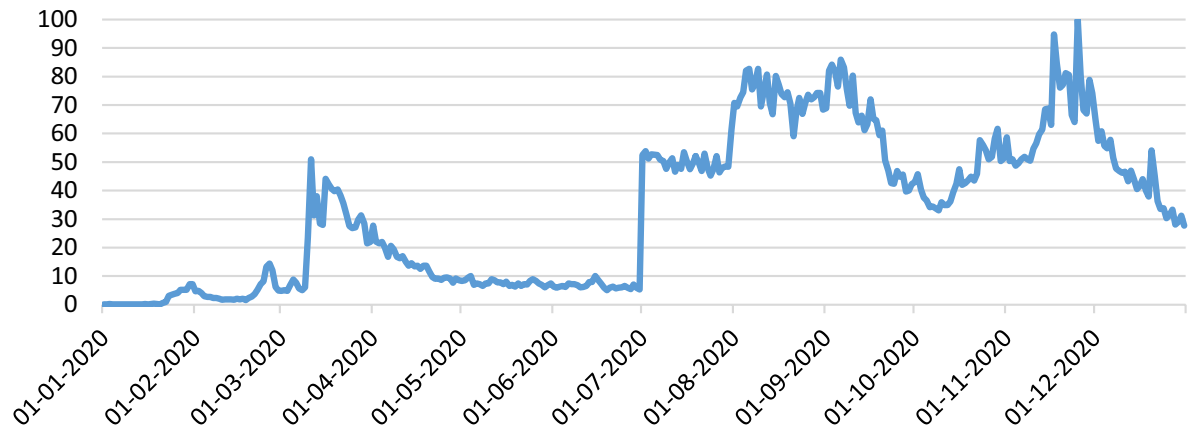

فيروس كورونا+كورونا+كوفيد 19 Coronavirus+Corona virus+Corona+Covid 19+Covid19+

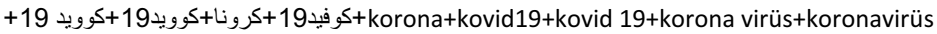

United Arab Emirates

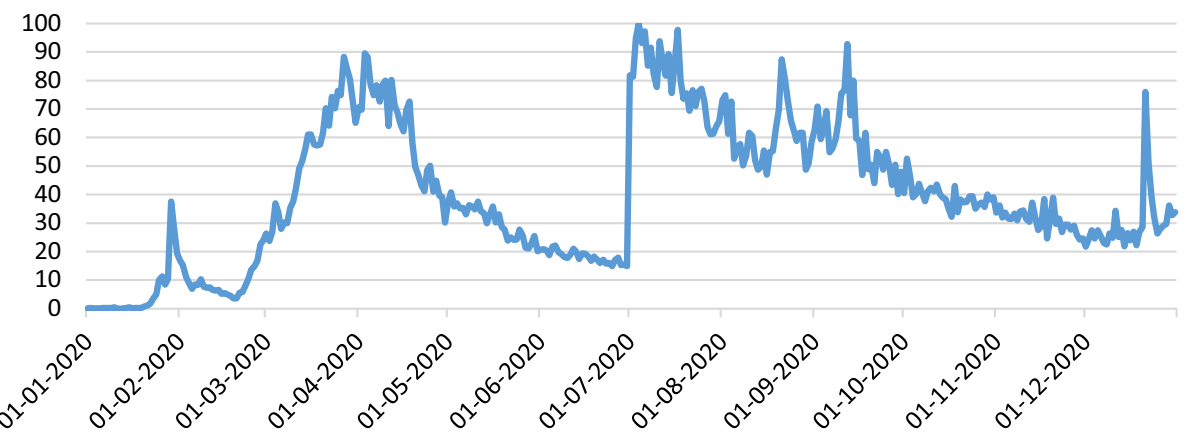

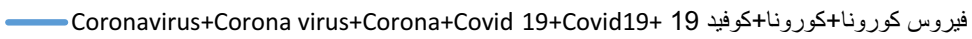

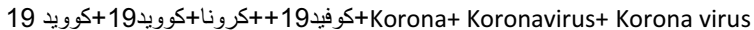

Fig. 1 (continued) 


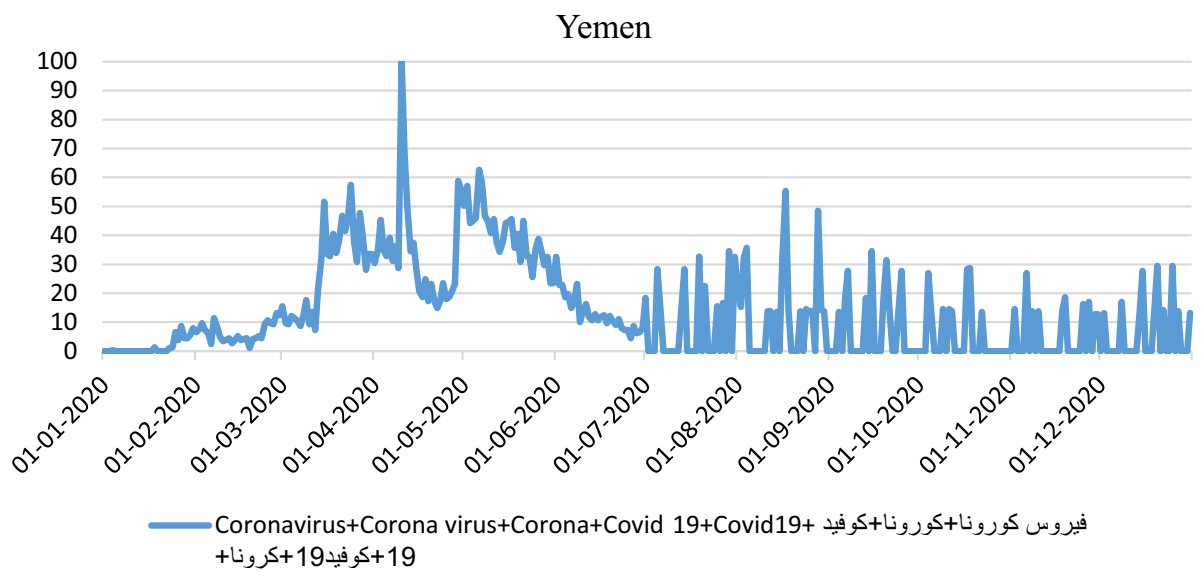

Fig. 1 (continued)

2020, to Dec 31, 2020, in Web of Science (WoS), Scopus, and PubMed (Table 5). Other ranks belonged to Turkey $(n=3,409)$ and Saudi Arabia $(n=2,705)$, respectively. Furthermore, the mean scientific productivity of the middle east scholars per country was 1040.93 .

\section{The association of the scientific productivity of the middle east scholars on scientific databases relating to the COVID-19 and the coronavirus-seeking behavior of the middle east people on Google from Jan 1, 2020, to Dec 31, 2020}

According to the result of the Kolmogorov-Smirnov test, we used the Spearman rank correlation to test the strength of the association between the RSVs for the informationseeking behavior towards the COVID-19 on Google and the scientific productivity of the scholars in the middle east countries.

As shown in Table 6, there was a positive and significant association (except Syria and Yemen) between the coronavirus-seeking behavior on Google and the scientific productivity of the middle east scholars on scientific databases relating to the COVID-19 $(P<0.001)$. In Syria and Yemen, this association was negative and significant. There was no significant association between the coronavirus-seeking behavior and the scientific productivity in Bahrain $(P=0.4)$ and Qatar $(P=0.07)$. Similarly, there was a positive and significant association (except Syria with $P=0.13$ and Yemen with $P=0.56)$ between the coronavirus-seeking behavior on Google and the confirmed cases $(P<0.001$ except United Arab Emirates with $P=0.02)$. The results indicated that there was a positive and significant association (except Yemen with $P=0.48$ and the United Arab Emirates with $P=0.09$ ) between the coronavirus-seeking behavior on Google and the number of deaths relating to COVID-19 $(P<0.001$ except Jordan with $P=0.003$ and Kuwait with $P=0.02$ ). Furthermore, there was a positive and significant association (except Jordan with $P=0.74$ ) between the scientific productivity of the middle east scholars and the number of deaths relating to COVID-19 $(P<0.001)$. Also, there was 


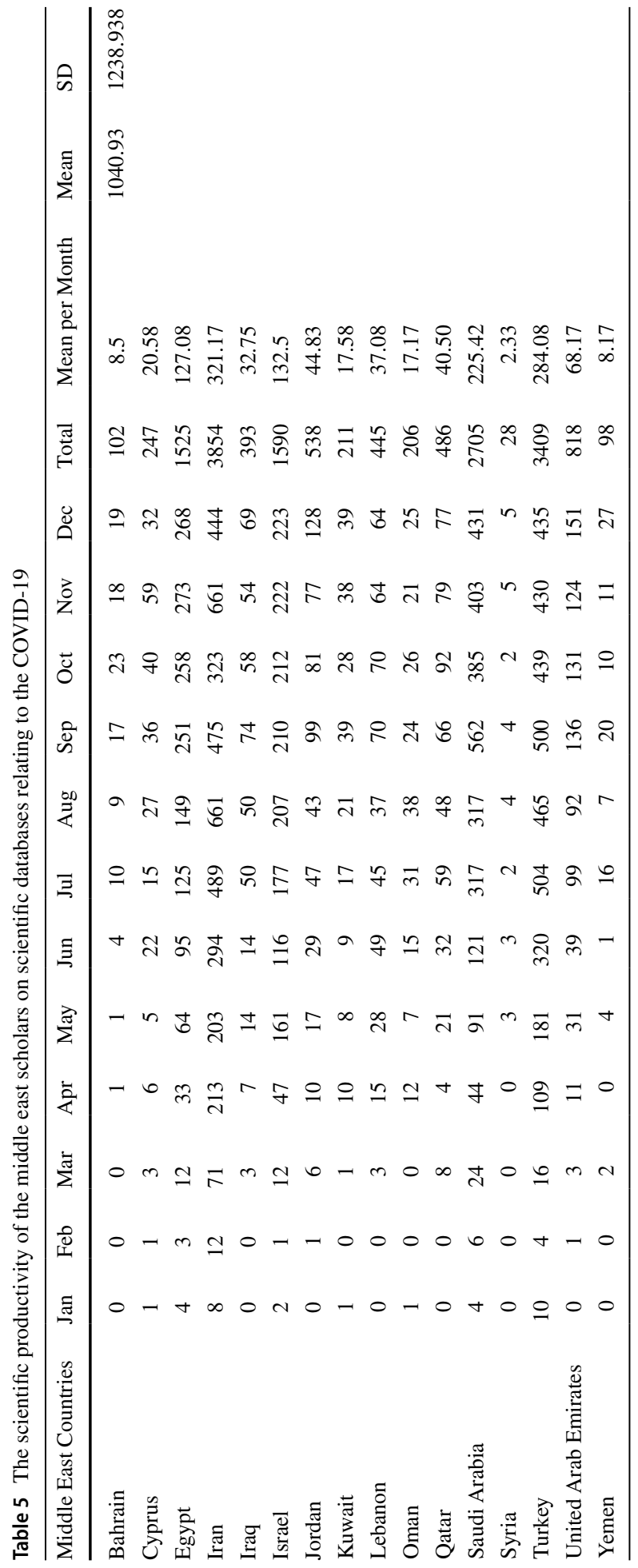


Table 6 The association between the scientific productivity of the middle east scholars on scientific databases relating to the COVID-19, the confirmed cases and deaths, and the coronavirus-seeking behavior of the middle east people on Google

\begin{tabular}{|c|c|c|c|c|c|c|c|c|c|c|}
\hline \multirow[t]{2}{*}{ Middle East countries } & \multicolumn{2}{|c|}{$\begin{array}{l}\text { Search on GT } \\
\text { and articles }\end{array}$} & \multicolumn{2}{|c|}{$\begin{array}{l}\text { Search on GT } \\
\text { and confirmed } \\
\text { Cases }\end{array}$} & \multicolumn{2}{|c|}{$\begin{array}{l}\text { Search on GT } \\
\text { and deaths }\end{array}$} & \multicolumn{2}{|c|}{$\begin{array}{l}\text { Deaths and } \\
\text { Articles }\end{array}$} & \multicolumn{2}{|c|}{$\begin{array}{l}\text { Confirmed } \\
\text { cases and } \\
\text { articles }\end{array}$} \\
\hline & $R$ & $P$ & $R$ & $P$ & $R$ & $P$ & $R$ & $P$ & $R$ & $P$ \\
\hline Bahrain & -0.04 & 0.4 & 0.31 & $<0.001$ & 0.17 & $<0.001$ & 0.43 & $<0.001$ & 057 & $<0.001$ \\
\hline Cyprus & 0.62 & $<0.001$ & 0.55 & $<0.001$ & 0.18 & $<0.001$ & 0.29 & $<0.001$ & 0.55 & $<0.001$ \\
\hline Egypt & 0.38 & $<0.001$ & 0.35 & $<0.001$ & 0.37 & $<0.001$ & 0.45 & $<0.001$ & 0.42 & $<0.001$ \\
\hline Iran & 0.27 & $<0.001$ & 0.43 & $<0.001$ & 0.59 & $<0.001$ & 0.74 & $<0.001$ & 0.84 & $<0.001$ \\
\hline Iraq & 0.33 & $<0.001$ & 0.42 & $<0.001$ & 0.44 & $<0.001$ & 0.60 & $<0.001$ & 0.68 & $<0.001$ \\
\hline Israel & 0.25 & $<0.001$ & 0.43 & $<0.001$ & 0.27 & $<0.001$ & 0.70 & $<0.001$ & 0.79 & $<0.001$ \\
\hline Jordan & 0.34 & $<0.001$ & 0.27 & $<0.001$ & 0.15 & 0.003 & 0.24 & 0.74 & 0.73 & $<0.001$ \\
\hline Kuwait & 0.21 & $<0.001$ & 0.31 & $<0.001$ & 0.12 & 0.02 & 0.43 & $<0.001$ & 0.49 & $<0.001$ \\
\hline Lebanon & 0.41 & $<0.001$ & 0.51 & $<0.001$ & 0.43 & $<0.001$ & 0.66 & $<0.001$ & 0.72 & $<0.001$ \\
\hline Oman & 0.30 & $<0.001$ & 0.38 & $<0.001$ & 0.20 & $<0.001$ & 0.50 & $<0.001$ & 0.36 & $<0.001$ \\
\hline Qatar & 0.37 & 0.07 & 0.41 & $<0.001$ & 0.20 & $<0.001$ & 0.20 & $<0.001$ & 0.22 & $<0.001$ \\
\hline Saudi Arabia & 0.48 & $<0.001$ & 0.46 & $<0.001$ & 0.49 & $<0.001$ & 0.67 & $<0.001$ & 0.39 & $<0.001$ \\
\hline Syria & -0.20 & $<0.001$ & 0.08 & 0.13 & 0.17 & $<0.001$ & 0.67 & $<0.001$ & 0.70 & $<0.001$ \\
\hline Turkey & 0.83 & $<0.001$ & 0.71 & $<0.001$ & 0.46 & $<0.001$ & 0.43 & $<0.001$ & 0.65 & $<0.001$ \\
\hline United Arab Emirates & 0.34 & $<0.001$ & 0.12 & 0.02 & 0.09 & 0.09 & 0.45 & $<0.001$ & 0.67 & $<0.001$ \\
\hline Yemen & -0.31 & $<0.001$ & 0.31 & 0.56 & 0.04 & 0.48 & 0.16 & $<0.001$ & 0.26 & $<0.001$ \\
\hline
\end{tabular}

a positive and significant association between the scientific productivity and the confirmed cases relating to COVID-19 $(P<0.001)$.

\section{Discussion}

Infodemiology is a rapidly growing field, which studies trends in online search behavior and internet activity. It provides new insights into population behavior and healthrelated phenomena, particularly during infectious disease outbreaks (Wong et al., 2021). The unprecedented rate at which scientific publications related to the COVID-19 are emerging (Haghani, Bliemer, Goerlandt, and $\mathrm{Li}, 2020$ ), and the vast increasing growth of the peoples' online searches on search engines concerning this pandemic, makes synthesizing health information demand as well as health information supply more significant than ever. The health information-seeking behavior on the web and public search queries on search engines could be considered health information demand. On the other hand, the scientific productivity of the scholars in scientific databases can be defined as health information supply (SeyyedHosseini et al., 2018). If we accepted the assumption that health information supply should be aligned with the health information demand, it would be desirable that the scholars' activities will have the same direction as the public's trend. In this context, we strived to explore online searches of the middle east 
people on Google relating to the COVID-19. Simultaneously, we aimed to investigate the scientific productivity of the scholars in prominent scientific databases in 2020.

According to the results, the middle east people utilized different keywords for searching the COVID-19 pandemic. It could be related to the diversity of spoken languages in this region. The most frequently used keywords by people in the middle east related to COVID-19 was described as follows: "coronavirus" in Bahrain, Cyprus, Jordan, Kuwait, Lebanon, Oman, Qatar, Syria, and United Arab Emirates; "انوروك" in Egypt, Iraq, and Yemen; "انورك" in Iran; "הנרוקروك" in Israel; "coronavirus" in Saudi Arabia; and "corona" in Turkey. The high use of some English keywords in the middle east region could be related to the outspread interactions with English-spoken countries. Another reason could be associated with the English-spoken citizens' attendance in the middle east countries.

Although the first confirmed case relating to the COVID-19 was observed on Jan 29, 2020, in the United Arab Emirates, we should remember that on this date, it might be other cases in the middle east that had not been confirmed by health agencies. In 2020, some middle east countries reached a peak of the COVID-19 one time; Bahrain (August), Iraq (October), Qatar (May), Saudi Arabia (June). Others reached a peak two times or more. On the whole, we can see a fluctuating growth of the COVID-19 confirmed cases. Previously, some studies pointed to the growing number of the confirmed cases relating to the COVID19 pandemic in 2020 (Sarkodie \& Owusu, 2020; Riberio et al. 2020; Lau et al., 2020). Alnaser, Abdel-Aty and Al-Ubaydli (2020) believed that the number of actual cases, especially in Bahrain, Saudi Arabia, and Egypt, might be attributed to several factors, including ambient temperature, population density, absolute humidity, lifestyle, physical immunity (type of nutrition), the accuracy of measurements, and the number of tests made. However, the first death relating to the COVID-19 was reported in February 2020 in Iran. Mortality had a swinging flow in middle eastern countries. The number of the confirmed cases and deaths in the Middle East region in 2020 could be associated with the more availability of diagnostics kits and health care facilities (Bi et al., 2020). Other reasons that cause the coronavirus-mortality could have related to the more densely populated areas (Xie \& Zhu, 2020), air pollution, and the aged population (Cristea, Noja, Stefea, \& Sala, 2020).

The relative search volumes of the middle east peoples' online search relating to the COVID-19 on Google showed an interesting output for each country. In Bahrain and Qatar, we could see about three peaks between February 2020 and July 2020. In Iran, Kuwait, Oman, Saudi Arabia, and Syria, we could observe two peaks nearly. Other countries had been experienced one prominent apex of coronavirus-seeking in 2020. Investigating the coronavirus-seeking behavior flow on Google showed that the pandemic search speed and acceleration reduced during the second half of 2020. It might be related to individuals' high sensibility toward the COVID-19 outbreak during the first six months of 2020. It might be attributed to other factors, including severe information needs and lack of awareness on coronavirus. Among the Middle East countries, Turkey is an exception. In Turkey, we could observe the fluctuating flow of coronavirus-seeking behavior. Despite other countries in the Middle East region, Turkish people sought coronavirus and its related keywords, on Google, especially in the second six months of 2020 (July, August, September, and November). Previously, findings indicated that the relative search volume of "kaplica", a Turkish term that means spas, during the COVID-19 pandemic, was statistically significantly decreased in the March 15-May 30, 2020; May 31-July 25, 2020; and July 26-September 19, 2020. Public interest in spas showed a moderate increase during the June-August period (Kardes, 2021). Our study approved the association between the RSVs on Google Trends and the number of confirmed cases and deaths relating to the 
COVID-19. In other previous studies, this association had been approved (Effenberger et al., 2020; Higgins et al., 2020; Husain et al., 2020; Mavragani, 2020; Rajan et al., 2020; Sharma \& Sharma, 2020; Sousa-Pinto et al., 2020). Some other researches indicated that Google Trends has the undeniable potential to map the information-seeking behavior of the users over the period (Ayers, Althouse, Noar, \& Cohen, 2014; Brigo et al., 2014; Kuehn, 2013; Otte, van Diessen, Bell, \& Sander, 2013; Pelat, Turbelin, Bar-Hen, Flahault, \& Valleron, 2009; Van Campen et al., 2014; Willard \& Nguyen, 2013).

Despite the growth of the confirmed cases relating to the COVID-19 in 2020, the number of searches on Google decreased. Some other coronavirus-related studies approved this previously (Mavragani, 2020; Rajan et al., 2020). It could be related to different reasons like increasing public awareness toward the pandemic, reducing coronavirus-related mortality, and improving the treatment methods. Therefore, it seems that the rate of attention of the Middle East people toward the COVID-19 decreased throughout the year 2020. It might be related to the gradual fading of the COVID-19 pandemic in the news box and media reports. Earlier, some studies highlighted the significant role of TV programs and national awareness in creating anxiety and panic among the public (Dehkordy, Carlos, Hall, \& Dalton, 2014; DeVilbiss \& Lee, 2014; Higgins et al., 2020; Walker \& Sulyok, 2020).

The scientific productivity of the middle east scholars in Wos, Scopus, and PubMed showed an increasing growth, with some fluctuation, in 2020. The highest number of scientific productivity belonged to Iran, Turkey, and Saudi Arabia, accordingly. The lowest number of scientific productivity belonged to Syria. It could be associated with Syrian difficulties in socio-economic concerns and civil war.

In the last step, the findings indicated a significant association between the confirmed cases and the scientific productivity of Middle East scholars. There was a positive and significant association between the number of deaths and the number of scientific publications (except Jordan). Also, there was a positive and significant association between online coronavirus-seeking behavior on Google (RSVs) and the confirmed cases (except Syria and Yemen). Furthermore, it was a positive relationship between RSVs and scientific productivity in the Middle East (except Bahrain and Qatar). From an infodemiological viewpoint, there is a significant correlation between coronavirus information demand and its information provision. Previously, some studies demonstrated the positive relationship between health information supply and demand for stomach cancer (SeyyedHosseini et al., 2018) and breast cancer (SeyyedHosseini, S., Shabani, Asemi, and CheshmehSohrabi, 2017).

\section{Conclusion}

Today, using an infodemiological approach, researchers could gain a better perception of the publics' needs. The actual scientific development occurs when the focus is on the real information need of the society. Infodemiology can play a crucial role in the initial drawing roadmap for future projects involving scientists and policymakers. With the onset of the COVID-19 pandemic worldwide, the importance of identifying peoples' needs in all aspects of the new virus is becoming more apparent than ever.

\section{Limitations}

Several inherent limitations of our research should be mentioned. (1) we only use the single search engine, Google, to retrieve data from the middle east countries. Thus, selection bias 
will be existing as Google only gathering the data of people who chose to get the information by using this search engine. (2) the detailed information about the procedures that Google implements to analyze this search behavior remains unclear. Therefore, controlling other factors that may affect our results would be impossible. (3) RSVs estimate relative changes in online interest and do not represent the interest of people with no Internet access. (4) A simple correlation between Google Trends (or the number of cases/deaths) may not be adequate, as there is an expectable time lag mirroring the period needed for a publication to be completed, peer-reviewed, accepted for publication, and published. (5) Internet penetration, government internet monitoring, and freedom of the press could be factors that affect the validity of the results in certain countries. These factors were out of the scope of our study. (6) The current investigation focuses on the selected keywords which directly related to the pandemic. So, the terms which may be relevant indirectly to the COVID-19 were not considered (e.g., if they search for preventive measures such as "social distancing" or "masks").

Acknowledgements The authors want to express their deep gratitude to Dr. Mohammadamin Erfanmanesh for his valuable comments.

Funding No funding was received for conducting this study.

\section{Declarations}

Conflict of interest The authors have no conflict of interests to declare that are relevant to the content of this article.

\section{References}

Alnaser, W. E., Abdel-Aty, M., \& Al-Ubaydli, O. (2020). Mathematical prospective of coronavirus infections in Bahrain, Saudi Arabia, and Egypt. Information Sciences Letters, 9(2), 51-64.

Ayers, J. W., Althouse, B. M., Noar, S. M., \& Cohen, J. E. (2014). Do celebrity cancer diagnoses promote primary cancer prevention? Preventive Medicine, 58, 81-84.

Baloch, Z., Ma, Z., Ji, Y., Ghanbari, M., Pan, Q., \& Aljabr, W. (2020). Unique challenges to control the spread of COVID-19 in the Middle East. Journal of Infection and Public Health., 13(9), 1247-1250.

Belli, S., Mugnaini, R., Baltà, J., \& Abadal, E. (2020). Coronavirus mapping in scientific publications: When science advances rapidly and collectively, is access to this knowledge open to society? Scientometrics, 124(3), 2661-2685.

Bi, Q., Wu, Y., Mei, S., Ye, C., Zou, X., Zhang, Z., \& Gao, W. (2020). Epidemiology and transmission of COVID-19 in 391 cases and 1286 of their close contacts in Shenzhen, China: A retrospective cohort study. The Lancet Infectious Diseases, 20(8), 911-919.

Brigo, F., Igwe, S. C., Ausserer, H., Nardone, R., Tezzon, F., Bongiovanni, L. G., \& Trinka, E. (2014). Why do people Google epilepsy? An infodemiological study of online behavior for epilepsy-related search terms. Epilepsy \& Behavior, 31, 67-70.

Cristea, M., Noja, G. G., Stefea, P., \& Sala, A. L. (2020). The impact of population aging and public health support on EU labor markets. International Journal of Environmental Research and Public Health, 17(4), 1439.

Dehkordy, S. F., Carlos, R. C., Hall, K. S., \& Dalton, V. K. (2014). Novel data sources for women's health research: Mapping breast screening online information seeking through Google Trends. Academic Radiology, 21(9), 1172-1176.

DeVilbiss, E. A., \& Lee, B. K. (2014). Brief report: Trends in US National autism awareness from 2004 to 2014: The impact of national autism awareness month. Journal of Autism and Developmental Disorders, 44(12), 3271-3273. 
Ebrahim, A. H., Saif, Z. Q., Buheji, M., AlBasri, N., Al-Husaini, F. A., \& Jahrami, H. (2020). COVID-19 information-seeking behavior and anxiety symptoms among parents. OSP Journal of Health Care and Medicine, 1(1), 1-9.

Effenberger, M., Kronbichler, A., Shin, J. I., Mayer, G., Tilg, H., \& Perco, P. (2020). Association of the COVID-19 pandemic with internet search volumes: A google trendstm analysis. International Journal of Infectious Diseases, 95, 192-197.

Eysenbach, G. (2002). Infodemiology: The epidemiology of (mis) information. The American Journal of Medicine, 113(9), 763-765.

Eysenbach, G. (2006). Infodemiology: Tracking flu-related searches on the web for syndromic surveillance. In AMIA annual symposium proceedings, pp. 244-248.

Fagherazzi, G., Goetzinger, C., Rashid, M. A., Aguayo, G. A., \& Huiart, L. (2020). Digital health strategies to fight COVID-19 worldwide: challenges, recommendations, and a call for papers. Journal of Medical Internet Research, 22(6), e19284.

Falagas, M. E., Ntziora, F., Makris, G. C., Malietzis, G. A., \& Rafailidis, P. I. (2009). Do PubMed and Google searches help medical students and young doctors reach the correct diagnosis? A pilot study. European Journal of Internal Medicine, 20(8), 788-790.

Haghani, M., Bliemer, M. C., Goerlandt, F., \& Li, J. (2020). The scientific literature on Coronaviruses, COVID-19 and its associated safety-related research dimensions: A scientometric analysis and scoping review. Safety Science, 129, 104806.

Heerfordt, C., \& Heerfordt, I. M. (2020). Has there been an increased interest in smoking cessation during the first months of the COVID-19 pandemic? A Google Trends Study. Public Health, 183, 6.

Higgins, T. S., Wu, A. W., Sharma, D., Illing, E. A., Rubel, K., Ting, J. Y., \& Alliance, S. F. (2020). Correlations of online search engine trends with coronavirus disease (COVID-19) incidence: Infodemiology study. JMIR Public Health and Surveillance, 6(2), 19702.

Homolak, J., Kodvanj, I., \& Virag, D. (2020). Preliminary analysis of COVID-19 academic information patterns: A call for open science in the times of closed borders. Scientometrics, 124(3), 2687-2701.

Hu, D., Lou, X., Xu, Z., Meng, N., Xie, Q., Zhang, M., \& Wang, F. (2020a). More effective strategies are required to strengthen public awareness of COVID-19: Evidence from Google Trends. Journal of Global Health. https://doi.org/10.7189/jogh.10.0101003

Hu, Z., Yang, Z., Li, Q., \& Zhang, A. (2020b). The COVID-19 infodemic: Infodemiology study analyzing stigmatizing search terms. Journal of Medical Internet Research, 22(11), 22639.

Husain, I., Briggs, B., Lefebvre, C., Cline, D. M., Stopyra, J. P., O’Brien, M. C., \& Countryman, C. (2020). Fluctuation of public interest in COVID-19 in the United States: Retrospective analysis of google trends search data. JMIR Public Health and Surveillance, 6(3), 19969.

Kardes, S. (2021). Public interest in spa therapy during the COVID-19 pandemic: Analysis of Google Trends data among Turkey. International Journal of Biometeorology. https://doi.org/10.1007/ s00484-021-02077-1

Kuehn, B. M. (2013). Scientists mine web search data to identify epidemics and adverse events. JAMA, 309(18), 1883-1884.

Lau, H., Khosrawipour, V., Kocbach, P., Mikolajczyk, A., Ichii, H., Schubert, J., \& Khosrawipour, T. (2020). Internationally lost COVID-19 cases. Journal of Microbiology, Immunology and Infection, 53, 454-458.

Mavragani, A. (2020). Tracking COVID-19 in Europe: Infodemiology approach. JMIR Public Health and Surveillance, 6(2), e18941.

Otte, W. M., van Diessen, E., Bell, G. S., \& Sander, J. W. (2013). Web-search trends shed light on the nature of lunacy: Relationship between moon phases and epilepsy information-seeking behavior. Epilepsy \& Behavior, 29(3), 571-573.

Pelat, C., Turbelin, C., Bar-Hen, A., Flahault, A., \& Valleron, A. J. (2009). More diseases tracked by using Google Trends. Emerging Infectious Diseases, 15(8), 1327.

Rajan, A., Sharaf, R., Brown, R. S., Sharaiha, R. Z., Lebwohl, B., \& Mahadev, S. (2020). Association of search query interest in gastrointestinal symptoms with COVID-19 diagnosis in the United States: Infodemiology study. JMIR Public Health and Surveillance, 6(3), e19354.

Ribeiro, M. H. D. M., da Silva, R. G., Mariani, V. C., \& dos Santos Coelho, L. (2020). Short-term forecasting COVID-19 cumulative confirmed cases: Perspectives for Brazil. Chaos, Solitons \& Fractals, 135, 109853.

Sarkodie, S. A., \& Owusu, P. A. (2020). Impact of meteorological factors on COVID-19 pandemic: Evidence from top 20 countries with confirmed cases. Environmental Research, 191, 110101.

SeyyedHosseini, S., Asemi, A., Shabani, A., \& CheshmehSohrabi, M. (2018). An infodemiology study on breast cancer in Iran: Health information supply versus health information demand in PubMed and Google Trends. The Electronic Library, 36(2), 258-269. 
SeyyedHosseini, S., Shabani, A., Asemi, A., \& CheshmehSohrabi, M. (2017). Scientific publication behavior versus information-seeking behavior: An infodemiological study on stomach cancer. Webology, 14(1).

Sharma, M., \& Sharma, S. (2020). The rising number of COVID-19 cases reflecting growing search trend and concern of people: A google trend analysis of eight major countries. Journal of Medical Systems. https://doi.org/10.1007/s10916-020-01588-5

Sousa-Pinto, B., Anto, A., Czarlewski, W., Anto, J. M., Fonseca, J. A., \& Bousquet, J. (2020). Assessment of the impact of media coverage on COVID-19-related google trends data: Infodemiology study. Journal of Medical Internet Research, 22(8), 19611.

van Campen, J. S., van Diessen, E., Otte, W. M., Joels, M., Jansen, F. E., \& Braun, K. P. (2014). Does saint Nicholas provoke seizures? Hints from Google trends. Epilepsy \& Behavior, 32, 132-134.

Walker, A., Hopkins, C., \& Surda, P. (2020). The use of google trends to investigate the loss of smell related searches during COVID-19 outbreak. International Forum of Allergy \& Rhinology, 10(7), 839-847.

Walker, M. D., \& Sulyok, M. (2020). Online behavioural patterns for Coronavirus disease 2019 (COVID$19)$ in the United Kingdom. Epidemiology \& Infection, 148, 1-14.

Willard, S. D., \& Nguyen, M. M. (2013). Internet search trends analysis tools can provide real-time data on kidney stone disease in the United States. Urology, 81(1), 37-42.

Wong, M. Y. Z., Gunasekeran, D. V., Nusinovici, S., Sabanayagam, C., Yeo, K. K., Cheng, C., \& Tham, Y. (2021). Telehealth demand trends during the COVID-19 pandemic in the top 50 most affected countries: Infodemiological evaluation. JMIR Public Health and Surveillance, 7(2), e24445.

Xie, J., \& Zhu, Y. (2020). Association between ambient temperature and COVID-19 infection in 122 cities from China. Science of the Total Environment, 724, 138201.

Zhang, L., Zhao, W., Sun, B., Huang, Y., \& Glänzel, W. (2020). How scientific research reacts to international public health emergencies: A global analysis of response patterns. Scientometrics, 124, 747-773. 